\title{
PENGEMBANGAN MODEL EVALUASI KINERJA SD PENYELENGGARA PENDIDIKAN INKLUSIF
}

\author{
N. Dede Khoeriah \\ Staf Pengajar PLB-FKIP Universitas Islam Nusantara \\ Jl. Soekarno Hatta no. 530 Bandung 40286 \\ nenden195830@gmail.com
}

\begin{abstract}
Abstrak
Penelitian ini bertujuan menghasilkan model evaluasi kinerja pendidikan inklusif (EKPI) di SD dengan menggunakan pendekatan kualitatif dan kuantitatif. Tahapan penelitian dimodifikasi dari model Borg \& Gall dengan melibatkan Kepala Sekolah, guru, dan orang tua. Data diperoleh melalui teknik Focus Group Discussion, wawancara, observasi, dan studi dokumentasi. Hasil penelitian menunjukkan bahwa (1) model EKPI merupakan salah satu model evaluasi yang baik berdasarkan hasil penilaian pakar maupun praktisi penyelenggara pendidikan inklusif di SD; (2) model evaluasi kinerja SD penyelenggara pendidikan inklusif memiliki tujuh komponen, yakni kepemimpinan, rencana strategis, fokus terhadap peserta didik-orang tua, analisis kebutuhan, fokus terhadap guru-staf, pengelolaan kelas inklusif, dan hasil; (3) evaluasi model EKPI dalam proses implementasi di SD mampu mengungkap data secara: (a) komprehensif; (b) faktual; (c) fleksibel; dan (d) berorientasi keragaman layanan.
\end{abstract}

Kata kunci: pengembangan model evaluasi, pendidikan inklusif, SD. 


\title{
DEVELOPING A MODEL OF PERFORMANCE EVALUATION OF ELEMENTARY SCHOOLS IMPLEMENTING INCLUSIVE EDUCATION
}

\author{
N. Dede Khoeriah \\ Staf Pengajar PLB-FKIP Universitas Islam Nusantara \\ J1. Soekarno Hatta no. 530 Bandung 40286 \\ nenden195830@gmail.com
}

\begin{abstract}
This study aims to produce a model of performance evaluation of elementary schools (ESs) implementing inclusive education by using qualitative and quantitative approaches. The research steps used the model by Borg \& Gall, involving principals, teachers, and students' parents. The data were collected through Focus Group Discussion (FGD), interviews, observations, document study, and discussions. Based on the results of the study, the following conclusions can be drawn. (1) The EKPI model is a good evaluation model. It is based on the result ofthe assessment by experts, usesrs and practitioners of inclusive education instruction; (2) The model of an evaluation of the performances of ESs implementing inclusive education has seven components, i.e. leadership, strategic plan, focus on students and parents, needs analysis, focus on teachers and staff, and inclusive class management, and product of the inclusive education implementation; (3) The EKPI model implemented in the elementri schools can reveal data (a) comprehensively, (b) factualy, and (c) flexibly, (d) it was also oriented to a variety of services.
\end{abstract}

Keywords: development of an evaluation model, inclusive education, elementary school. 


\section{Pendahuluan}

Pendidikan inklusif menjadi isu yang menarik perhatian berbagai pihak, karena diyakini dapat memberikan peluang yang besar kepada anak berkebutuhan khusus sesuai dengan bakat, minat dan kemampuannya untuk berpartisipasi lebih luas dalam berbagai jenis dan jenjang pendidikan sebagaimana anak-anak reguler pada umumnya. Undang-Undang RI pasal 12 bab V no (1) b. menjelaskan bahwa setiap peserta didik pada setiap satuan pendidikan berhak mendapatkan pelayanan pendidikan sesuai dengan bakat, minat dan kemampuannya. Hallahan \& Kauffman (2003:44) menegaskan bahwa, "Full inclusion means all students with disabilities are placed in their neighborhood schools in general education classrooms for the entire day, general education teachers have the primery responsibility for students with disabilities".

Dengan demikian semua anak berkebutuhan khusus diberi kesempatan untuk belajar bersama-sama dengan anak reguler dalam lingkungan dan pembelajaran yang seluas-luasnya, sedangkan guru-guru sekolah reguler memiliki kewajiban memberikan layanan sesuai terhadap keberagaman peserta didik. Hal tersebut dinyatakan dalam Permendiknas Nomor 70 Tahun 2009 pasal 2 tujuan pendidikan inklusif yaitu (a) memberikan kesempatan yang seluas-luasnya kepada semua peserta didik yang memiliki kelainan fisik, emosional, mental, dan sosial, atau memiliki potensi kecerdasan dan/atau bakat istimewa untuk memperoleh pendidikan yang bermutu sesuai dengan kebutuhan dan kemampuannya; (b) mewujudkan penyelenggaraan pendidikan yang menghargai keanekaragaman, dan tidak diskriminatif bagi semua peserta didik sebagaimana yang dimaksud pada huruf a.

Deklarasi dan kebijakan pendidikan inklusif, telah direalisasikan pemerintah Indonesia seperti yang tercantum pada data Direktorat Pendidikan Luar Biasa (2009) bahwa "pada tahun 2008, terdapat 790 lembaga pendidikan penyelenggara inklusif ABK (cacat) dengan jumlah siswa 10.405 dan sekolah inklusif ABK (akselerasi) dengan jumlah siswa 4.671 di seluruh Indonesia". Khusus di Provinsi Jawa Barat terdapat 111 sekolah dasar penyelenggara inklusif ABK (cacat), total siswa berkebutuhan khusus se- 
banyak 864 siswa dengan guru pembimbing khusus/SLB sejumlah 150 dan guru reguler/kepala sekolah sebanyak 50 orang.

Kenyataan di sekolah-sekolah menunjukkan bahwa kegiatan pendidikan inklusif di Jawa Barat belum berjalan sesuai dengan yang diharapkan. BPG SLB Dinas Pendidikan Provinsi Jawa Barat (2008:16-17) menjelaskan hasil monitoring dan evaluasi antara lain: (1) masih kurang dukungan dari kepala sekolah; (2) kurang tersedianya aksesibilitas fisik bagi ABK; (3) kurang berperannya SLB sebagai resource center (pusat sumber); dan (4) belum adanya perubahan sistem evaluasi sesuai dengan kondisi ABK.

Berdasarkan survei awal yang dilakukan peneliti pada SD Al Biruni, SDN Rancaloa, SD Plus Al-Ghifari, SDN Putraco dan SDN Tunas Harapan di Provinsi Jawa Barat, menunjukkan bahwa (1) jumlah guru tidak seimbang dengan jumlah siswa. Hal tersebut tidak sesuai dengan per-aturan penyelenggaraan PLB (1991) bahwa tenaga kependidikan sekurangkurangnya terdiri dari seorang guru kelas, dan seorang tenaga ahli, sebagai standar tidak dijadikan sebagai acuan dalam penyelenggaraan program inklusif; (2) belum memiliki paramedis sehingga para orang tua harus meluangkan waktu mencari tenaga paramedis di luar sekolah dan siswa meninggalkan proses pembelajaran; (3) guru yang menangani ABK kurang memahami program pembelajaran yang diindividualisasikan dan kesulitan melaksanakan asesmen; (4) implementasi pendidikan inklusif belum sesuai dengan standar proses, yaitu prinsip memperhatikan perbedaan individu siswa, standar pendidik dan tenaga kependidikan.

Meskipun demikian, pelaksanaan pada beberapa SD penyelenggara pendidikan inklusif menunjukkan dampak positif dengan terselenggaranya layanan keberagaman peserta didik, yakni (1) jumlah peserta didik berkebutuhan khusus melebihi kuota yang ditentukan, hal ini menunjukkan bahwa SD penyelenggara tersebut memiliki kualitas yang diharapkan masyarakat; (2) SD penyelenggara pendidikan inklusif dapat meningkatkan kesadaran orang tua dalam memberikan layanan pada anaknya, terbukti orang tua mencari paramedis untuk memberikan terapi terhadap anaknya; dan (3) meningkatnya kemampuan sebagian guru reguler dalam melayani peserta didik meskipun ditambah peserta didik berkebutuhan khusus. 
Berdasarkan uraian tersebut, untuk mengetahui sejauh mana penyelenggaraan pendidikan inklusif diperlukan suatu model evaluasi terhadap kinerja SD penyelenggara pendidikan inklusif. Tanpa evaluasi, para pengambil kebijakan akan kesulitan membuat keputusan strategis berkenaan dengan penyelenggaraan pendidikan inklusif. Hal ini sejalan dengan pendapat Dunn (1998: 609) memandang "evaluasi memberi informasi yang valid dan dapat dipercaya mengenai kinerja kebijakan”. Dengan demikian, evaluasi dimaksudkan untuk memberikan informasi mengenai kebijakan dan pertimbangan dalam rangka mengambil keputusan.

Dikaitkan dengan layanan pendidikan inklusif yang sedang dilaksanakan, evaluasi kinerja SD penyelenggara pendidikan inklusif perlu didukung oleh instrumen standar yang dapat mengungkap informasi objektif, sehingga mendorong sekolah yang menyelengarakan inklusif meningkatkan mutu pengelolaannya. Model seperti itu diharapkan dapat digunakan oleh pengelola pendidikan inklusif untuk mengetahui tingkat keberhasilan sekolahnya dalam menyelenggarakan pendidikan inklusif. Terkait dengan latar belakang tersebut, penelitian ini bertujuan untuk mengembangkan sebuah model evaluasi penyelenggara pendidikan inklusif yang dapat memberikan informasi dengan tepat bagi pengawas, pimpinan sekolah dan guru serta bermanfaat secara optimal bagi pelaksanaan pendidikan inklusif di SD.

Model Evaluasi Kinerja Pendidikan Inklusif (Model EKPI) di SD

Model ini menggunakan pendekatan evaluasi proses dan hasil dari model CIPP dan mengadaptasi kriteria model Performance Excellence in Education yang dikembangkan oleh Baldrige Award Criteria for Education. Model tersebut dipilih memperhatikan beberapa pertimbangan, yaitu (1) telah digunakan selama puluhan tahun dalam pengembangan kriteria standar Performance Excellence in Education dan meluncurkan Baldrige Award Criteria for Education; (2) dikembangkan oleh lembaga independen dalam wadah The American Society for Quality (ASQ); (3) aspek dan indikator mutu yang dikembangkan sangat rinci dan operasional serta senantiasa dilakukan penyempurnaan secara berkala; (4) menyediakan berbagai informasi penting dan lengkap yang dengan mudah dapat diakses melalui situs di 
internet; dan (5) melakukan pengukuran mutu secara komprehensif dan melibatkan orang tua sebagai subjek dalam menentukan mutu.

Blazey, et al. (2009) memberi penjelasan bahwa lembaga pendidikan berkinerja unggul memiliki seperangkat kriteria meliputi kepemimpinan, perencanaan strategis, fokus terhadap siswa dan stakeholders, fokus terhadap staf administratif serta guru, proses manajemen, pengukuran dan analisis, serta outcomes merujuk pada hasil-hasil kinerja lembaga. Spesifikasi model tersebut mencakup delapan komponen dalam pedoman implementasi Pendidikan Inklusif, yang disesuaikan dengan Education Criteria for Performance Excellencedari Malcolm Baldrige yaitu:

(1) input siswa dan kurikulum (bahan ajar) ada pada kriteria 1 (Leadership) dan 2 (Strategic Planning);

(2) manajemen (pengelolaan) kelas inklusif ada pada kriteria 6 (Educational and Support Management Process) dan kiteria 7 (Organizational Performance Result);

(3) lingkungan (sekolah, masyarakat, dan keluarga) ada pada kriteria 6 (Educational and Support Process Management) dan kriteria7 (Organizational Performance Result);

(4) tenaga kependidikan ada pada kriteria 5 (Faculty and Staff Focus) dan kriteia4 (Information and Analysis);

(5) sarana-prasarana dan dana ada pada kriteria 4 (Information and Analysis), kriteria 5 (Faculty and Staff Focus), dan kriteria 7 (Organizational Performance Result);

(6) pembelajaran ada pada kriteria 3 (Sudent and Stakeholder Focus) dan kriteria 7 (Organizational Performance Result).

Aplikasi dari pengertian, tujuan dan prinsip keunggulan kinerja lembaga Malcolm Baldrige dalam pelaksanaan evaluasi kinerja sekolah, digunakan untuk menyusun model evaluasi kinerja pendidikan inklusif (EKPI). Model ini merupakan panduan dan petunjuk praktis bagi lembaga penyelenggara pendidikan inklusif, kepala sekolah, guru dan orang tua dalam mengevaluasi pelaksanaan pendidikan inklusif di SD. Komponenkomponen yang dievaluasi dapat diwujudkan dalam Gambar 1. 


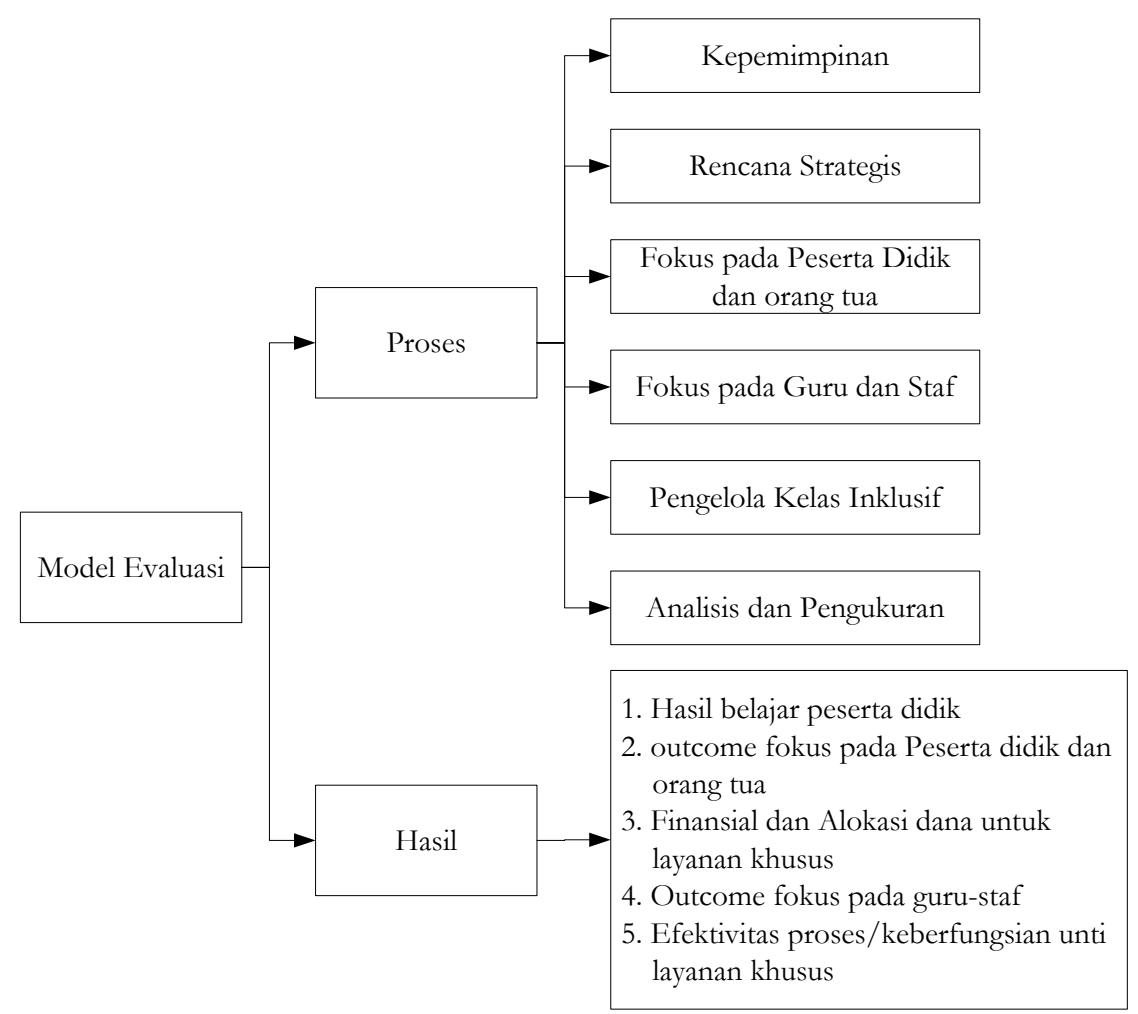

Gambar 1. Komponen-komponen Model Evaluasi

\section{Metode Penelitian}

Penelitian pengembangan ini bertujuan menghasilkan suatu produk yaitu model Evaluasi Kinerja Pendidikan Inklusif (EKPI) di SD dan meneliti kualitas produk tersebut. Prosedur penelitian mengacu pada model Borg \& Gall (1983) dengan memodifikasi 10 tahapan penelitian menjadi 4 tahap utama.

Penelitian pendahuluan mengkaji kerangka konseptual model melalui berbagai literatur dan meneliti praktik-praktik kinerja SD penyelenggara pendidikan inklusif. Kegiatan ini menghasilkan analisis dan deskripsi model 
faktual kinerja SD penyelenggara pendidikan inklusif yang dilaksanakan selama ini.

Tahap pengembangan model dimulai dengan perencanaan model evaluasi kinerja SD, yakni penyusunan model konseptual berupa adaptasi Baldrige Award Criteria for Education ke dalam model evaluasi kinerja SD penyelenggara pendidikan inklusif. Kegiatan ini menghasilkan draf desain dan perangkat model evaluasi sebagai pengembangan bentuk produk awal. Selanjutnya, draf desain dan berbagai perangkat model evaluasi dipersiapkan seperti, lembar validasi untuk model evaluasi beserta perangkat dan instrumennya, yaitu meliputi lembar penilaian instrumen: kinerja SD; hasil performa organisasi; efektivitas model evaluasi kinerja SD penyelenggara pendidikan inklusif; dan panduan evaluasi untuk divalidasi oleh para pakar dalam memperoleh masukan, judgment konstruk, dan kelayakan secara konseptual. Berdasarkan hasil validasi, kemudian dievaluasi, direvisi, dan disempurnakan sehingga menjadi model hipotetis yang siap diuji coba secara empiris.

Uji coba model melibatkan subjek penelitian di SD penyelenggara pendidikan inklusif. Selanjutnya, dilakukan evaluasi dan revisi untuk dilanjutkan pada uji coba kedua di SD Plus Al-Ghifari. Model yang telah direvisi dan sudah disempurnakan kemudian diterapkan pada empat sekolah penyelenggara pendidikan inklusif, agar dapat dievaluasi sejauh mana hasil penerapannya. Jika hasil penerapan tersebut masih ada hal-hal yang perlu dibenahi, maka perlu dilakukan perbaikan sebagaimana mestinya. Hasilnya merupakan sebuah model Evaluasi Kinerja Pendidikan Inklusif (EKPI) beserta instrumen dan perangkatnya.

Penelitian ini menggunakan pendekatan kualitatif dan pendekatan kuantitatif secara bersama-sama. Mengacu pada pendapat Creswell (2012: 5), terdapat tiga model penggunaan pendekatan kualitatif, kuantitatif, dan campuran (mixed) kedua pendekatan tersebut dalam satu penelitian. Dalam penelitian ini dipilih pencampuran kedua pendekatan, karena pendekatan kuantitatif dan pendekatan kualitatif dilakukan secara terpadu dan saling mendukung.

Metode penelitian yang digunakan adalah deskriptif karena penggunaan metode tersebut memungkinkan untuk mempelajari, menggambar- 
kan, dan menafsirkan data kondisi serta relasi antardata. Diungkapkan oleh Best (1977: 145-146) bahwa metode ini bersentuhan dengan hubungan antarvariabel dan pengujian teori.

Validasi pakar merupakan uji coba skala kecil yang dilakukan setelah model evaluasi beserta instrumen dan perangkatnya disusun. Proses validasi pakar dalam penelitian ini menggunakan FGD (Focus Group Discussion), dan melakukan validasi ahli sebanyak tiga tahap. Teknik ini digunakan dengan harapan dapat diperoleh model evaluasi yang valid dan reliabel.

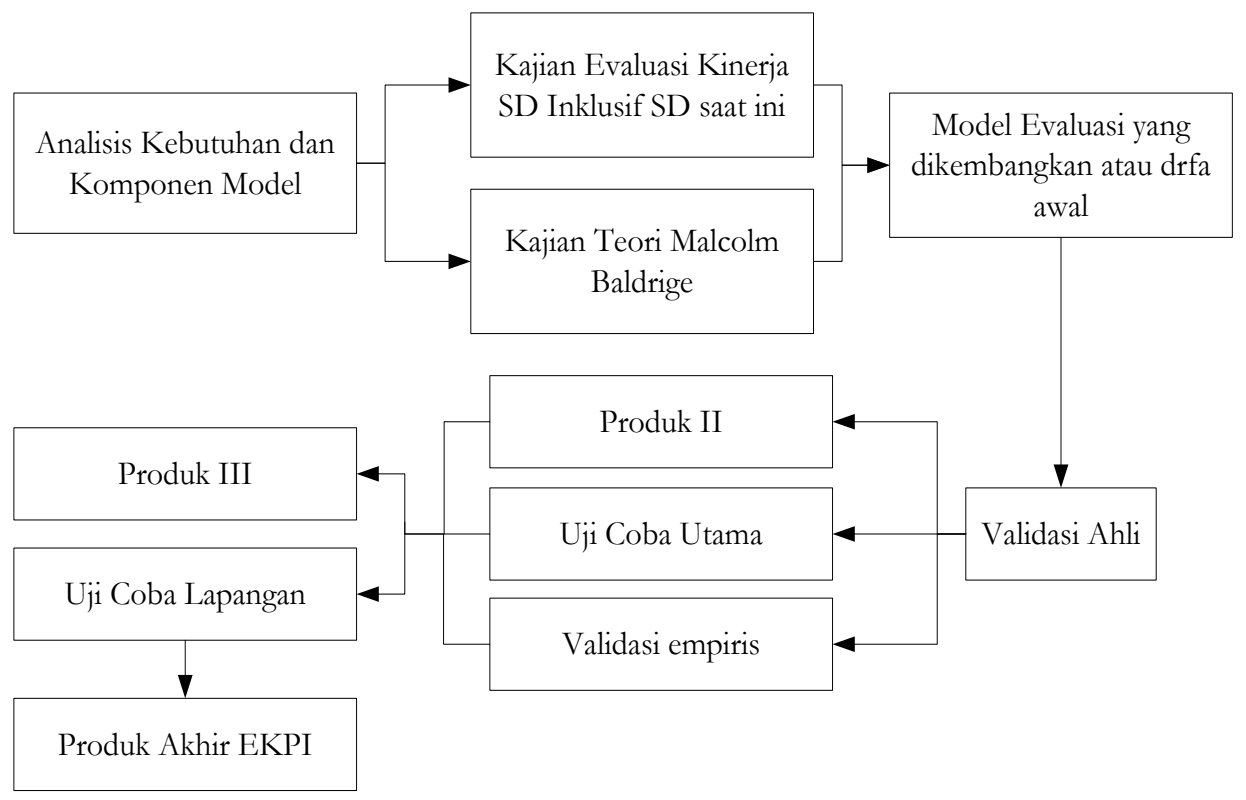

Gambar 2. Skema Prosedur Pengembangan Model EKPI

Data yang diperoleh melalui hasil uji coba dianalisis secara deskriptif melalui validitas isi, baik melalui pendekatan kualitatif maupun kuantitatif. Pendekatan kuantitatif dalam penelitian ini menggunakan program SPSS versi 18.0, dengan menggunakan teknik Principal Component Analysis, dan estimasi reliabilitas instrumen didasarkan pada konsistensi internal dengan 
formula Alpha-Cronbach. Pendekatan kualitatif dengan menggunakan informan review dan teknik triangulasi. Pengumpulan data baik pada validasi empiris tahap awal, validasi tahap akhir maupun untuk validasi data dilakukan dengan kuesioner. Hasil akhir dari model yang telah dianalisis merupakan desain model yang baik sebagai hasil pengembangan.

\section{Hasil Penelitian dan Pembahasan}

Pengembangan model evaluasi ini meliputi tiga hal, yaitu pengembangan instrumen proses dan hasil, model evaluasi, dan pedoman evaluasi. Model yang dikembangkan ini adalah model evaluasi bagi SD penyelenggara pendidikan inklusif berdasarkan temuan kondisi empiris, kemudian mengadaptasi dari performance excellent in education dari Malcolm Baldrige, dilengkapi teori-teori yang berkaitan dengan evaluasi serta prinsip pendidikan inklusif yang meliputi komponen dan indikator kualitas proses dan hasil. Selanjutnya, hal itu disebut model evaluasi kinerja pendidikan inklusif (EKPI) di SD. Penetapan komponen dan indikator kualitas proses dan hasil pendidikan inklusif dilakukan melalui kajian konseptual, teoretis, dan empiris di lapangan dengan menggunakan metode survei, Focus Group Discussion (FGD), seminar, uji coba utama, dan uji coba operasional.

Untuk melihat layak tidaknya model ini, dilihat dari hasil analisis penilaian pakar atau expert judgment, para praktisi dan keefektifan model melalui empat tahap yaitu FGD, uji coba pendahuluan, uji coba utama dan uji coba operasional untuk melihat efektivitas model. FGD dilaksanakan yang pertama di Yogyakarta 28 Mei 2011 dihadiri sembilan ahli terdiri dari lima ahli evaluasi pendidikan, tiga ahli PLB, satu ahli PGSD, dan dua praktisi dari SLB. Kedua, dilaksanakan di Bandung 2 Juni 2011 dihadiri oleh para praktisi berjumlah enam orang, terdiri dari dua pengawas PLB, dua kepala SLB dan dua guru SD inklusif. Melalui FGD, ditemukan dan menetapkan konsep kualitas proses dan hasil pelaksanaan pendidikan inklusif di SD, model evaluasi dan pedoman evaluasi. Selain itu, draf awal didiskusikan dan meng-input banyak masukan atau rekomendasi mengenai penyederhanaan instrumen, kejelasan instrumen, kejelasan petunjuk eva- 
luasi, objektivitas instrumen pengumpul data, dan objektivitas panduan evaluasi.

Setelah dilakukan revisi sesuai rekomendasi hasil FGD, maka diadakan seminar dengan melibatkan 11 orang terdiri dari tiga pakar PLB, satu pakar PGSD, satu pakar BP dosen PLB, dua pengawas dari SD dan SLB, dua kepala sekolah dari SD dan SLB, dan dua guru SD sebagai guru pendamping khusus (GPK). Sebelum model diujicobakan pada subjek coba, model dan instrumen telah divalidasi baik oleh para ahli PLB, PGSD, evaluasi pendidikan maupun para praktisi melalui uji coba pendahuluan dengan melibatkan 12 orang praktisi, tiga pakar PLB, satu PGSD dan satu ahli evaluasi.

Uji coba pada tahap kedua yang memberikan penilaian, melibatkan 34 orang terdiri dari lima ahli PLB, dua ahli manajemen, satu ahli evaluasi, dua kepala SD penyelenggara pendidikan inklusif, dua pengawas SLB, 16 guru SD Al-Ghifari dan delapan orang tua dari peserta didik yang berada di SD Al-Ghifari. Orang tua yang diminta mengisi kuesioner diambil yang kebetulan pada hari dilaksanakan uji coba berada di sekolah mulai dari kelas satu sampai kelas enam. Selain kepala sekolah dan guru dari SD AlGhifari, penilai melibatkan kepala sekolah dan pengawas dari sekolah lain baik secara langsung bertemu ataupun melalui e-mail.

Penilai yang terlibat pada tahap operasional atau ketiga berjumlah 74 orang, yakni pimpinan sekolah sebanyak 4 orang, pakar evaluasi pendidikan sebanyak 2 orang, dosen PLB sebanyak 2 orang, dosen PGSD 1 orang, guru sebanyak 36 orang termasuk guru SDN Putraco sebanyak 7 orang, orang tua siswa 7 orang. Guru SD BPI sebanyak 7 orang, psikolog 1 orang, orang tua siswa 5 orang. Guru SDN Tunas Harapan sebanyak 10 orang, dan orang tua siswa 8 orang. Guru SDN Gegerkalong Girang sebanyak 10 orang dan orang tua siswa 8 orang. Adapun rekapitulasi hasil validasi terhadap model evaluasi kinerja pendidikan inklusif di SD disajikan dalam Tabel 1.

Hasil penilaian pada tahap pendahuluan terhadap kelayakan instrumen kualitas penyelenggaraan pendidikan inklusif di SD meliputi (1) kejelasan petunjuk angket proses kinerja SD inklusif; (2) kejelasan instrumen kepemimpinan; (3) kejelasan instrumen rencana strategis; (4) ke- 
jelasan instrumen fokus terhadap siswa dan orang tua; (5) kejelasan instrumen analisis kebutuhan; (6) kejelasan instrumen fokus pada guru dan staf; (7) kejelasan instrumen proses mengelola kelas inklusif; (8) penggunaan bahasa Indonesia baku; (9) rumusan pernyataan yang mudah dipahami; (10) penggunaan kata dan kalimat yang jelas; (11) bentuk dan ukuran huruf; (12) tata tulis dan penggunaan tanda baca; dan (13) format penulisan pada penilaian fokus pendahuluan ini ditemukan rerata skor total sebesar 3,70. Jika dikonsultasikan dengan standar penilaian dalam panduan evaluasi, maka rerata skor total tersebut berada pada interval $>3,6-3,93$ termasuk kategori baik sehingga instrumen tersebut dapat digunakan dengan perbaikan.

Tabel 1. Hasil Validasi Instrumen Kualitas Peyelenggaraan Pendidikan Inklusif

\begin{tabular}{|c|c|c|c|c|c|c|c|c|c|c|c|c|c|c|c|}
\hline \multirow{2}{*}{\multicolumn{2}{|c|}{$\begin{array}{r}\text { Tahap Banyaknya } \\
\text { Responden }\end{array}$}} & \multicolumn{13}{|c|}{ Rerata Skor Butir } & \multirow{2}{*}{$\begin{array}{l}\text { Rerat } \\
\text { Total }\end{array}$} \\
\hline & & 1 & 2 & 3 & 4 & 5 & 6 & 7 & 8 & 9 & 10 & 11 & 12 & 13 & \\
\hline 1 & 12 & 3,62 & 3,70 & 3,62 & 3,70 & 3,62 & 3,80 & 3,62 & 3,80 & 3,70 & 3,62 & 3,93 & 3,90 & 3,60 & 3,70 \\
\hline 2 & 24 & 3,77 & 4,00 & 3,85 & 3,93 & 3,90 & 4,04 & 3,93 & 4,04 & 3,90 & 3,80 & 4,00 & 3,93 & 3,85 & 3,91 \\
\hline 3 & 74 & 4,00 & 4,10 & 4,10 & 4,20 & 4,30 & 4,00 & 4,10 & 4,30 & 4,10 & 4,30 & 4,30 & 4,20 & 3,80 & 4,13 \\
\hline
\end{tabular}

Penilaian tahap kedua menunjukkan rerata skor total berada pada interval $>3,4-4,2$ yang berarti kategori baik dan mengalami peningkatan dari rerata 3,70 menjadi 3,91. Pada pengembangan tahap kedua ini, masih terdapat 5 rekomendasi dari para validator dan merupakan dasar untuk dilakukannya revisi instrumen sebelum dilaksanakan pengembangan tahap ketiga.

Hasil analisis dengan menggunakan bantuan program SPSS for Windows 18.0 menunjukkan bahwa Cronbach's Alpha untuk semua instrumen $\geq 0,7$ (di atas 0,7) yang menunjukkan bahwa instrumen tersebut dapat dikatakan reliabel (Hair et al., 2006: 115). Sementara mengacu pada hasil analisis faktor dengan menggunakan teknik Principal Component Analysis, menunjukkan bahwa hampir semua nomor butir instrumen baik instrumen kualitas (kepemimpinan, rencana strategis, fokus terhadap peserta didik- 
orang tua, analisis kebutuhan, fokus terhadap guru-staf dan mengelola kelas inklusif), memiliki faktor loading lebih dari $\geq 0,5$ sebagai batas minimal validitas butir instrumen. Dengan demikian, seluruh instrumen dapat dikatakan valid.

Revisi instrumen pada penilaian tahap ketiga dibandingkan dengan hasil penilaian pada uji coba tahap kedua, mengalami sedikit kenaikan yakni dari rerata total skor 3,91 menjadi 4,14. Hasil penilaian tahap ketiga ini menunjukkan bahwa retata skor total pada tahap tiga berada pada interval $>3,4-4,2$ yang berarti klasifikasi baik sehingga instrumen layak digunakan.

Tabel 2. Hasil Validasi Instrumen Hasil Pelaksanaan Pendidikan Inklusif di SD

\begin{tabular}{ccccccccccccccc}
\hline Tahap $\begin{array}{c}\text { Banyaknya } \\
\text { Responden }\end{array}$ & 1 & 2 & 3 & 4 & 5 & 6 & 7 & 8 & 9 & 10 & 11 & 12 & $\begin{array}{c}\text { Rerata } \\
\text { Total }\end{array}$ \\
\cline { 4 - 10 } & 12 & 3,62 & 3,80 & 3,70 & 3,62 & 3,92 & 3,90 & 3,70 & 3,60 & 3,90 & 4,07 & 4,00 & 4,15 & 3,70 \\
1 & 24 & 4,03 & 3,90 & 3,80 & 3,90 & 4,03 & 3,90 & 4,00 & 3,90 & 3,96 & 4,00 & 4,10 & 4,10 & 3,97 \\
2 & 74 & 4,20 & 3,90 & 3,90 & 4,10 & 4,10 & 3,90 & 4,30 & 4,20 & 4,20 & 4,30 & 4,20 & 4,20 & 4,13 \\
3 & 74
\end{tabular}

Hasil penilaian tahap pertama terhadap kelayakan instrumen hasil kinerja pelaksanaan pendidikan inklusif di SD meliputi (1) kejelasan petunjuk angket hasil kinerja SD inklusif; (2) kejelasan instrumen hasil prestasi belajar peserta didik; (3) kejelasan instrumen outcome fokus terhadap peserta didik dan orang tua; (4) kejelasan instrumen finansial dan penggunaan dana; (5) kejelasan instrumen outcome fokus pada guru dan staf; (6) kejelasan instrumen keberfungsian layanan khusus; (7) penggunaan bahasa Indonesia baku; (8) rumusan pernyataan yang mudah dipahami; (9) penggunaan kata dan kalimat yang jelas; (10) bentuk dan ukuran huruf; (11) tata tulis dan penggunaan tanda baca; dan (12) format penulisan, ditemukan rerata skor total sebesar 3,83 yang berada pada interval $>3,4-4,2$ termasuk kategori baik sehingga instrumen tersebut dapat digunakan. Walaupun demikian, sebelum instrumen diuji coba pada tahap kedua, maka terlebih dulu dilakukan perbaikan-perbaikan mengacu pada rekomendasi yang diberikan oleh validator. 
Hasil penilaian tahap kedua menunjukkan bahwa retata skor total sebesar 3,97, berada pada interval $>3,4-4,2$ yang berarti kategori baik. Rerata skor total hasil penilaian tahap kedua mengalami sedikit peningkatan dari rerata 3,83 menjadi 3,97, dan masih terdapat rekomendasi dari para validator untuk dilakukannya perbaikan instrumen sebelum dilaksanakan pengembangan tahap ketiga.

Penilaian tahap ketiga menunjukkan retata skor total sebesar 4,13. Rerata skor total hasil penilaian tahap ketiga mengalami peningkatan dari rerata 3,97 menjadi 4,13. Hal ini berarti bahwa instrumen baik untuk digunakan di jenjang sekolah dasar di segala klasifikasi sekolah. Terjadinya peningkatan rerata skor tersebut menunjukkan bahwa ada hubungan yang positif dengan revisi yang dilakukan sebelumnya.

Estimasi reliabilitas dilakukan pada masing-masing sekolah baik di SDN Putraco, SD BPI, SDN Gegerkalong Girang, dan SDN Tunas Harapan. Berdasarkan hasil analisis dengan menggunakan bantuan program SPSS for Windows 18.0 seluruh angket hasil penyelenggaraan pendidikan inklusif komponen prestasi belajar peserta didik, outcome fokus pada peserta didik-orang tua, finansial dan alokasi dana, outcome fokus pada guru-staf, dan efektivitas keberfungsian unit layanan khusus memiliki Cronbach's Alpha di atas 0,7 . Hal itu menunjukkan bahwa seluruh instrumen dapat dikatakan reliabel. Dengan demikian, semua instrumen hasil penyelengaraan pendidikan inklusif dapat diterapkan di semua level sekolah dasar baik sekolah yang favorit swasta, maupun negeri.

Hasil analisis faktor dengan menggunakan teknik Principal Component Analysis menunjukkan bahwa hampir semua nomor butir instrumen hasil pelaksanaan pendidikan inklusif memiliki faktor loading lebih dari $\geq 0,5$. Dengan demikian, seluruh instrumen dapat dikatakan valid, maka dapat disimpulkan bahwa data hasil pelaksanaan pendidikan inklusif berdistribusi normal, sehingga memenuhi syarat untuk dianalisis lebih lanjut.

Hasil penilaian tahap pertama terhadap model EKPI meliputi: (1) objektivitas instrumen pengumpul data; (2) objektivitas panduan evaluasi; (3) kepraktisan instrumen pengumpul data; (4) kepraktisan panduan evaluasi; (5) ekonomis dalam penggunaan waktu; (6) ekonomis dalam penggunaan biaya; dan (7) ekonomis dalam penggunaan tenaga, ditemukan re- 
rata total skor sebesar 3,75, dan pada penilaian kedua, rerata skor total sebesar 3,96, dari penilaian tersebut dapat disimpulkan bahwa model evaluasi termasuk klasifikasi baik sehingga layak digunakan untuk mengevaluasi program pendidikan inklusif di SD. Penilaian kedua ini rerata total skor mengalami kenaikan dari 3,75 menjadi 3,96 walaupun tetap pada klasifikasi baik. Kenaikan tersebut berkorelasi dengan diadakannya revisi pada instrumen pengumpul data dan model evaluasi setelah tahap satu.

Tabel 3. Hasil Penilaian Model Evaluasi

\begin{tabular}{|c|c|c|c|c|c|c|c|c|c|}
\hline \multirow[t]{2}{*}{ Tahap } & \multirow{2}{*}{$\begin{array}{l}\text { Banyaknya } \\
\text { Responden }\end{array}$} & \multicolumn{7}{|c|}{ Rerata Skor Butir } & \multirow{2}{*}{$\begin{array}{c}\text { Rerata } \\
\text { Total }\end{array}$} \\
\hline & & 1 & 2 & 3 & 4 & 5 & 6 & 7 & \\
\hline 1 & 12 & 3,70 & 3,80 & 3,85 & 3,85 & 3,77 & 3,70 & 3,77 & 3,75 \\
\hline 2 & 24 & 4,00 & 3,93 & 4,04 & 4,00 & 3,90 & 3,85 & 3,97 & 3,96 \\
\hline 3 & 30 & 4,25 & 4,00 & 3,92 & 4,16 & 3,90 & 4,09 & 4,09 & 4,07 \\
\hline
\end{tabular}

Pada penilaian ketiga, rerata total skor sebesar 4,07 yang termasuk klasifikasi baik sehingga layak digunakan untuk mengevaluasi program pendidikan inklusif di SD. Penilaian ketiga ini rerata total skor mengalami sedikit kenaikan dari 3,96 menjadi 4,07. Hasil analisis tersebut menunjukkan bahwa evaluasi model EKPI beserta perangkatnya memiliki sifat objektivitas, praktikabilitas dan efisiensi atau ekonomis yang cukup baik.

Tabel 4. Hasil Penilaian Panduan Evaluasi

\begin{tabular}{cccccccccc}
\hline Tahap & $\begin{array}{c}\text { Banyaknya } \\
\text { Responden }\end{array}$ & \multicolumn{9}{c}{ Rerata Skor Butir } & \multirow{2}{*}{ Rerata Total } \\
\cline { 2 - 8 } & 1 & 2 & 3 & 4 & 5 & 6 & 7 & \\
\hline 1 & 12 & 4,00 & 3,85 & 3,77 & 3,92 & 4,00 & 3,85 & 3,85 & 3,90 \\
2 & 24 & 4,07 & 3,90 & 3,96 & 3,85 & 4,00 & 3.90 & 3.90 & 3,94 \\
3 & 30 & 4,30 & 4,30 & 4,00 & 4,10 & 4,30 & 4,10 & 4,17 & 4,20 \\
\hline
\end{tabular}

Hasil penilaian pertama terhadap panduan evaluasi meliputi aspek: (1) kejelasan petunjuk umum evaluasi kinerja SD inklusif; (2) kejelasan langkah-langkah proses evaluasi; (3) kejelasan rekomendasi hasil evaluasi; (4) kejelasan waktu pelaksanaan evaluasi; (5) penggunaan bahasa Indonesia 
baku; (6) rumusan pernyataan mudah dipahami; dan (7) penggunaan kata dan kalimat yang jelas, didapatkan rerata skor total adalah sebesar 3,90. Mengacu pada standar penilaian, maka rerata skor tersebut menunjukkan bahwa panduan evaluasi masuk pada kategori baik. Sebelum penilaian kedua panduan evaluasi diperbaiki. Hal ini mengacu pada rekomendasi dari para validator.

Hasil penilaian kedua tahap uji coba utama terhadap panduan evaluasi didapatkan rerata skor total adalah sebesar 4,00 yakni mengalami sedikit kenaikan, yaitu dari 3,90 menjadi 4,00. Hal ini menunjukkan bahwa hasil perbaikan setelah tahap pertama memiliki makna semakin baiknya panduan evaluasi. Meskipun demikian, sebelum dilakukan penilaian tahap ketiga, aspek-aspek yang terkait dengan panduan evaluasi dilakukan perbaikan, sesuai dengan masukan dari para validator.

Dari hasil penilaian tahap ketiga terhadap panduan evaluasi didapatkan rerata skor total sebesar 4,20. Dengan mengacu pada standar penilaian pada panduan evaluasi, maka rerata skor tersebut menunjukkan pada kategori sangat baik, meskipun pada tahap paling minim dan dapat dipergunakan. Penilaian tahap ketiga ini mengalami kenaikan, yaitu dari 4,00 menjadi 4,20, yakni klasifikasi sangat baik. Dari hasil ketiga tahap penilaian tersebut, dapat disimpulkan bahwa model evaluasi beserta instrumen dan panduan evaluasi yang dikembangkan dalam penelitian ini sudah dapat dimanfaatkan atau dipergunakan oleh penyelengara pendidikan atau kepala sekolah sebagai acuan untuk melaksanakan evaluasi. Dengan adanya model evaluasi kinerja SD penyelenggara pendidikan inklusif yang dilengkapi dengan instrumen dan panduan, diharapkan hasil evaluasi kinerja SD inklusif segera disampaikan kepada penyelenggara, pimpinan dan guru atau pihak yang terkait dengan perbaikan pelaksaan pendidian iklusif.

\section{Simpulan}

Berdasarkan hasil analisis data sebagaimana disajikan di atas, dapat ditarik kesimpulan sebagai berikut. Pertama, model EKPI merupakan salah satu model evaluasi yang baik berdasarkan hasil penilaian pakar maupun 
praktisi penyelenggara pendidikan inklusif di SD dengan konstruk model diadaptasi dari performance excellent in education dari Malcolm Baldrige, berdasar pada prinsip pendidikan inklusif yang dilengkapi teori-teori yang berkaitan dengan evaluasi dan dilakukan melalui kajian konseptual, teoretis, dan empiris di lapangan dengan menggunakan metode survei, Focus Group Discussion (FGD), seminar, uji coba utama, dan uji coba operasional. Kedua, model Evaluasi Kinerja Pendidikan Inklusif (EKPI) memiliki dua aspek evaluasi kinerja, yaitu aspek proses yang meliputi 6 komponen, yakni kepemimpinan, rencana strategis, fokus pada peserta didik-orang tua, fokus pada guru dan staf, mengelola kelas inklusif, dan analisis pengukuran; dan aspek hasil yang meliputi lima komponen, yakni prestasi peserta didik, outcome fokus terhadap peserta didik-orang tua, outcome fokus terhadap gurustaf, finansial dan penggunaan dana, dan efektivitas proses keberfungsian layanan khusus. Seluruh komponen mengandung 233 butir pernyataan yang dilengkapi dengan kata pengantar, petunjuk pengisian, dan pedoman evaluasi. Ketiga, evaluasi model EKPI dalam proses implementasi di SD dapat mengungkap data yang diperlukan secara komprehensif berdasarkan fakta di lapangan, fleksibel dan berorientasi keragaman layanan.

Berdasarkan simpulan di atas, dapat dirumuskan rekomendasi berikut ini. Pertama, evaluasi model EKPI dapat dijadikan sebagai alternatif bagi pengawas, penyelenggara sekolah inklusif, dan pimpinan sekolah penyelenggara pendidikan inklusif. Kedua, kepala sekolah dan atau pengawas sebelum mengimplementasikan model EKPI, perlu memberikan pendidikan dan latihan terlebih dahulu kepada guru-guru, staf dan tenaga terkait dengan layanan pendidikan inklusif. Ketiga, model EKPI dapat dikembangkan lebih lanjut agar lebih sempurna, terutama untuk mengevaluasi proses pembelajaran ramah bagi keragaman peserta didik. Keempat, model ini dapat dikembangkan dengan pembuatan program rumah data, untuk memudahkan proses evaluasi, sehingga evaluator dapat mengoreksi data yang ada dan memasukkannya ke dalam program dengan cepat. 
Jurnal Penelitian dan Evaluasi Pendidikan

\section{Daftar Pustaka}

Best, J. W. (1977). Research in Education, New Delhi: Prentice Hill India.

Blazey, et al. (2009). Insight to Performance Exellence in Education 2001: An Inside Look at the 2001 Baldridge Award Criteria for Education. Winconsin: ASQ Quality Press.

BPG SLB Dinas Pendidikan Prov Jabar. (2008). Laporan Monitoring dan Evaluasi Kegiatan Pelatihan Pendidik dan Tenaga Kependidikan SLB Negeri dan Swasta di Jawa Barat 2008. Bandung: Disdik Prov Jabar

Borg, W. R.\& Gall, M. D. (1983).Educational Research: An introduction, Fourth edition. New York : Longman, Inc.

Creswell, J.W. (2012). Research Design: Pendekatan Kualitatif,Kuantitatif, dan Mixed. Penerjemah Achmad Fawaid. Yogyakarta: Pustaka Belajar.

Depdikbud. (1993). Peraturan Pemerintah Republik Indonesia No 72 Tabun 1991 Tentang Pendidikan Luar Biasa. Jakarta:Depdikbud.

Depdiknas. (2003). Undang-undang Republik Indonesia NO. 20 Tabun 2003 tentang Sistem Pendidikan Nasional. Jakarta: Depdiknas

Direktorat PLB. (2009). Pendidikan Khusus dan Pendidikan Layanan Khusus. Jakarta: Direktorat Pendidikan Luar Biasa.

Dunn, W. N. (1998). Public Policy Analysis: An Introduction, Second Edition. Terjem: "Pengantar Analisis Kebijakan Publik." Yogyakarta: Gadjah Mada University Press

Hair, J. F., Black, W. C., Babin, B. J., Anderson, R. E., \& Tatham, R. L. (2006). Multivariate data analysis. Sixth edition. New Jersey: Pearson Education Inc.

Hallahan, D.P., \& Kauffman, J, M. (2003). Exceptional Learners. Ninth Edition. Allyn and Bacon. USA.

Kementrian Pendidikan Nasional. (2011). Permendiknas Nomor 70 Tahun 2009. Jakarta : Direktorat PPK-LK Dikdas. 